both dry and humid tropical climates. The experiments were undertaken in a small Torry kiln in which tropical conditions were simulated.

Even in dry tropical climates, fish drying can normally be carried out for only $8 \mathrm{~h}$ a day because at sundown the temperature falls and the humidity increases. An attempt was made to determine whether hanging, stacking or pressing fish overnight gave the shortest drying time. The results of these experiments indicated that there might be some advantage in pressing during the later stages of drying, thus enabling the moisture to equilibrate. Further work with more refined apparatus will bo required before definite conclusions can be drawn.

The 'available lysine' contents of threo specimens of Tilapia nilotica from Uganda were determined by Carpenter's method in order to ascertain if any damage had been caused by the different methods of drying. The three specimens had been either fresh-frozen, or sun-dried, or fresh-frozen and later dried in a Torry kiln. It was found that the fresh-frozen fish contained most available lysine $(10.7 \mathrm{~g} / 16 \mathrm{~g}$ nitrogen) as would be expected, the sun-dried fish contained least $(6 \cdot 1 \mathrm{~g} / 16 \mathrm{~g}$ nitrogen) and the kiln-dried fish gave an intermediate value $(6 \cdot 9 \mathrm{~g} / 16 \mathrm{~g}$ nitrogen). Those concerned with this aspect of the Institute's work were surprised to find that the loss of available lysine in sun-drying was as great as that occurring in the manufacture of fish meal where much highor temperatures are used. However, as only three fish wero used in the experiments the results were not, at the time of preparing the report, regarded as conclusive. They indicated, however, that further work on these lines would be worthwhile. Factors, other than protein deterioration, which are important in tho nutritive value of fish, have not been examined as part of this investigation.
An officer was seconded to the Government of Aden during October 1962-March 1963 to investigate the problems involved in preparing dried fish for export. A survey of the curing methods in present-day use in Aden suggested that minor improvements in technique would enable the processors to make much better products. A series of fish-curing experiments was carried out and the crew of a Fisheries Department vessel was trained to demonstrate the methods evolved to local fishermen. These demonstrations included dry-salting in closed vessols instead of salting in open kench piles, proper washing of tho fish using brine, and drying on raised racks in the shade instead of throwing the fish on the sand in the open sun. The success of these methods was illustrated by the fact that products made by the demonstrators fetched higher prices than the traditional products in local markets. Two fish-curing stations wore designed for experimental use and built so that the experiments and demonstrations could be continued after the officers' departure.

The problem of insect infestation in Aden of dried fish during preparation and in storage was also examined. Early in the assignment it became obvious that this was a serious problem. A preliminary report on insect infestation was, therefore, prepared and forwarded to the Department of Technical Co-oporation, since it was obvious that insect infestation should be investigated by an entomologist specializing in stored products.

The report recommends that domonstration of the improved curing methods should continue, that samples of the products made should be sent to overseas markets for evaluation and that experiments with species of fish at present under-exploited should continue. It is also recommended that the possibility should be investigated of erecting commercial fish-curing stations for communal use.

\title{
ROYAL INSTITUTE OF TECHNOLOGY, STOCKHOLM
}

$\mathrm{P}$ ROF. H. ERDTMAN, of tho Kungliga Tekniska Högskolan, Stockholm, has provided an intoresting account of the Royal Institute of Technology, Stockholm, which was founded in 1827 as a 'humble' school of technology (May and Baker Bulletin, 6, No. 2; May 1964). The staff of the Institute then consisted of one director, two professors, two other toachers and eight other employees, including one steward and one porter. Instruction was in the fundamental subjects of "general natural knowledge, i.e., physics and chemistry, with particular reference to those of the goneral laws of Nature that find their most common applications in industry", and it was required to be "popular and practical rather than strictly scientific". In 1876 the Institute was transformed into an institute of technology, but in 1907 it still had only two professors of chemistry, ono in 'technical chemistry' and one in 'general chemistry'. The present Kungliga Tekniska Högskolan, has nine departments and about eighty professors. There are about 750 other employees, of whom some 500 are teaching and research assistants, and in all about 4,000 studonts.

The Department of Chemistry now has twelve professors and three other senior lecturers, each in charge of his own branch of study: analytical chemistry, inorganic chemistry, organic chemistry, nuclear chemistry, physical chemistry, wood chemistry, chemical technology, polymer technology, paper technology, collulose technology, food chomistry (biochemistry), fermentation chemistry, applied electro-chemistry and corrosion, heat technology, and chemical engineering equipment.

The degrees awarded by the Institute include civilingenjor, teknologie licentiat, and teknologie doktor. Tho time normally required for the first degree is four years, although in practice $4 \cdot 5-5$ years are often needed. 'The licentiate takes a further two or three yoars, and the doctorate yet another two or throo or even longer. The licentiate corresponds roughly to an American, British or German $\mathrm{Ph} \mathrm{D}$., and the doctorate approximates to a British D.Se.

Students enter the Institute of Technology at the age of eighteen to twenty, and, owing to compulsory military service, malo students are about twenty-five when they pass their civilingenjorsexamen. Approximately soventy freshmen are admitted annually to the Department of Chemistry, of whom about 10 per cent are women. Admission is compotitive and far more students apply for admission than there are places. During the first two years, basic subjects are studied, for example, mathematics, physics, inorganic and organic chemistry, machine element design, and mechanies. The first courses in chomistry aro elomentary 'general courses', and all firstand second-year courses must be completed before starting the third-year course. During this and the fourth year, applied subjects are studied, and more advanced chomistry courses are available, but these are compulsory only for students who have chosen the relevant field of spocialization. During the fourth year, specialization is much more intensive. Finally, for the civilingenjorsexamen, the student must carry out a small research project, roquiring about three months work; about four months of practical experioneo in industry is also required.

Every student who has obtained a civilingenjor's degree may continue his studies for the licentiate and then go on to seek the degree of teknologie doktor. Foreign students who can show that they have taken a degree comparable to that of civilingenjor may be admitted to study for the licentiate and then for the doctor's degree by special 
permission from the Governing Board of Sweden's three institutes of technology. The studies for the licentiate degree are much freor than those for that of civilingenjor. There are practically no lectures or any special courses, and only seminars to be attended. The main emphasis here is on scientific or technological research. For the doctor's degree a fairly long and thorough scientific training is required, and it is not uncommon for a doktorand (candidate for a doctorate) to have some ten to fifteen published papers.
Work for the higher degrees is genorally sponsored by the research councils. As a rule, it is the professor who applies to these councils for fellowships for his students, and thus remains more or less responsible for the progress of their research work. In the applied subjects collaboration is often established with the appropriate industry. When the doktorand feels that he is ready for his doktorsdisputation he writes a review article covering his publications. This articlo constitutes his formal doctor's dissertation and is followed by a disputation.

\title{
THE ONTARIO RESEARCH FOUNDATION
}

\begin{abstract}
$\mathrm{T}$ HE annual report for 1963 of the Ontario Foundation* includes the reports of the director, the director of research and departmental directors, and a list of scientific and technical papers published during the year, as well as details of scientific and technical assistance given to outside organizations. Reference is made to the increasing number of requests received for the development of new instrumentation and measurement techniques for application in industry, and also to the growing acceptance of the Institute's project type of contract research. An intensive investigation of the chemistry of sporulation has been undertaken and an improved method of ballistically disintegrating spores has shown that the release of protein and dipicolinic acid by ruptured spores is followed by the release of an esterase.

Research was continued on high-purity iron and low alloy steel to determine the fundamental causes of fatigue by means of ultrasonic wave attenuation. In biochemistry much information was obtained regarding the part played by enzymes in the glucose metabolism of yeast. Further work was continued on the processing of fats and oils, emphasis being placed on the hydrogenation of fish oils and on the selectivity of hydrogenation of fats and oils in relation to operating variables. Fundamental information on the properties of chrysotile was accumulated with particular interest in the longer grades of fibres. In the Division of Organic Chemistry work continued to be concentrated on wood chemistry, including the utilization of wood, pulping, paper-making and paper additives. However, factors in the mechanism of absorption of wet-
\end{abstract}

* Ontario Research Foundation. Annual Report 1963. Pp. 70. (Toronto: Ontario Research Foundation, 1964.) strength resins on paper were also investigated, and an investigation of the 4-methoxycyclohexene oxides and their ring opening reactions with nucleophilic reagents was completed. A detailed examination of many black spruce trees gave new information on the complex of interactions involving the character of the foliage, rate of growth and morphology of the wood.

In parasitology it was discovered that a lung worm of deer was responsible for paralytic disoase in moose, and evidence was also gained that the same worm may cause paralytic disease in sheep. An intensive survey of small mammals was initiated to assess their role as intermediate hosts for the lung worms of carnivorous animals. Work on the attraction of different flies to different birds indicated the importance of smell, sight and touch stimuli. In physical chemistry, as part of a programme to develop non-nuclear uses of uranium, the possible application of uranium compounds as catalysts was investigated, for example, in the dehydrogenation of 1 -butene to $1: 3$ butadiene. A process was developed for producing a flexible sheet for foamed-in-place shelters under field conditions, which can be operated down to $-40^{\circ} \mathrm{C}$, and the use of the sheet in shelter construction was demonstrated.

The work of the Physics Department was concerned ehiefly with measurements on materials and development of instruments using new principles. The Department of Physiography completed a map of the surface features and glacial deposits for the area between the Kawartha Lakes and Algonquin Park, while a survey of 2,500 acres of the Humberstone peat bog was made to determine the amount of fibrous Sphagnum peat remaining.

\section{TIDAL COMPONENTS IN HURRICANE DEVELOPMENT}

\section{BY DONALD A. BRADLEY}

\author{
Research Division, College of Engineering, New York University
}

\begin{abstract}
A
TOTAL of 269 individual hurricanes evolved out of North Atlantic tropical depressions during the 60 years 1899-1958, as catalogued in a standard data source ${ }^{1}$. The criterion for ranking a tropical storm as a hurricane is its attainment of sustained winds of force 12 on the Beaufort scale, at which intensity stage the pressure drops rapidly and distinct organization of the system into inward-spiralling bands takes place. The dates of transition from tropical storm to hurricane status of the 269 historical cyclones in question have been investigated as frequency distributions within frames of reference defined by lunar cycles.

The convention among investigators of lunar relationships to weather ${ }^{2-4}$ is to express the Moon's position in any cycle as hundredths of the cycle elapsed, measuring
\end{abstract}

from the fiducial of the cycle. Each hundredth part thereby denotes a class-interval $3^{\circ} 36^{\prime}$ in width. Table 1 presents the four lunar variables of key concern in this enquiry.

The lower limit of the first interval (decimal 0.00), it should be clarified, lies $1^{\circ} 48^{\prime}$ in advance of the given fiducial point so that the interval straddles the fiducial

Table 1. Decimal Reckoning of Lunar Positions

\begin{tabular}{|c|c|c|c|c|c|}
\hline \multirow{2}{*}{$\begin{array}{l}\text { Lunar } \\
\text { cycle }\end{array}$} & \multirow{2}{*}{$\begin{array}{l}\text { Mean } \\
\text { length } \\
\text { (d) }\end{array}$} & \multirow[t]{2}{*}{ Fiducial } & \multirow{2}{*}{$\begin{array}{c}\text { Mean } \\
\text { daily } \\
\text { increment } \\
\text { (r) }\end{array}$} & \multicolumn{2}{|c|}{$\begin{array}{l}\text { Moving total } \\
\text { time equivalents }\end{array}$} \\
\hline & & & & $\begin{array}{c}10 \text {-unitit } \\
\text { (d) }\end{array}$ & $\begin{array}{l}\text { 13-unit } \\
\text { (d) }\end{array}$ \\
\hline $\begin{array}{l}\text { Synodic } \\
\text { Tropical }\end{array}$ & $\begin{array}{l}29 \cdot 5306 \\
27 \cdot 3216 \\
27 \cdot 2122\end{array}$ & $\begin{array}{l}\text { New Moon } \\
\text { Vernal point } \\
\text { Ascending node }\end{array}$ & & & $\begin{array}{l}3 \cdot 839 \\
3 \cdot 552 \\
3 \cdot 538\end{array}$ \\
\hline & & & & $2 \cdot 755$ & 3.582 \\
\hline
\end{tabular}

